\title{
Excito-repellency effect of deltamethrin on triatomines under laboratory conditions
}

\author{
Efeito excito-repelente da deltametrina sobre triatomíneos \\ em condições de laboratório
}

\author{
Liléia Diotaiuti', Claysson Marques Penido', Holbiano Saraiva de Araújo', \\ Christopher John Schofield ${ }^{2}$ and Cláudio Teixeira Pinto ${ }^{3}$
}

\begin{abstract}
This work demonstrates that deltamethrin in low doses produces an excito-repellency effect on triatomines, as already observed for mosquitoes. A wooden box covered with a cloth impregnated with deltamethrin at doses of 2.5 and $5 \mathrm{mg}$ ai $/ \mathrm{m}^{2}$ was utilized for the experiment. The triatomine species studied were Triatoma infestans, Panstrongylus megistus, Rhodnius neglectus and Triatoma sordida. Adults were released in one of the sides of the box and their position was noted in subsequent periods. The observations were realized on the day the cloth was impregnated and subsequently repeated at 30 and 60 days for T. sordida; on day 120, the remaining species were included. Insect mortality and attempts at flight from the box were also observed. Excitorepellency was evident for all species and doses up to day 120. The only species that attempted to fly was P. megistus. The excito-repellency effect may be considered as an additional advantage to the insecticide power, as it should be able to prevent the installation of new colonies by females that fly into the homes, and at the moment of the spraying, it should promote the flushing out of triatomines from the wall crevices and from other shelters.
\end{abstract}

Key-words: Excito-repellency. Triatominae. Deltamethrine. Pyrethroid. Chagas'disease. Control.

Resumo No presente trabalho procurou-se constatar se a deltametrina em baixas doses produz excito-repelência em triatomíneos, conforme já observado para mosquitos. $O$ experimento foi realizado utilizando-se uma caixa de madeira recoberta com tecido impregnado com deltametrina nas doses de 2,5 e $5 \mathrm{mg} \mathrm{ia} / \mathrm{m}^{2}$. As espécies de triatomíneos estudadas foram o T. infestans, P. megistus, R. neglectus e T. sordida. Exemplares adultos eram liberados em um dos lados da caixa, e a posição dos mesmos era anotada em períodos subseqüentes. A experiência foi realizada no dia da impregnação do tecido, e repetida aos 30 e 60 dias para o T. sordida; aos 120 dias incluíram-se as demais espécies. Também foram observadas a mortalidade dos insetos e a tentativa de fuga da caixa através do vôo. A excito-repelência foi evidente para todas as espécies e doses até o $120^{\circ}$ dia. A única espécie que voou foi o P. megistus. O efeito excito-repelente pode ser considerado uma vantagem adicional ao poder do inseticida pois dificultaria a instalação de novas colônias a partir de fêmeas que ingressassem nas casas através do vôo, além de promover o desalojamento de exemplares presentes nas frestas das paredes e outros esconderijos.

Palavras-chaves: Excito-repelência. Triatominae. Deltametrina. Piretróide. Doença de Chagas. Controle.

\footnotetext{
1. Laboratório de Triatomíneos e Epidemiologia da Doença de Chagas, Centro de Pesquisas René Rachou, Fundação Oswaldo Cruz, MS, Belo Horizonte, MG, Brasil. 2. London School of Hygiene and Tropical Medicine, Keppel St., London WC1E 7HT, England. 3. Hoechst Schering AgrEvo do Brasil Ltda, Av. das Nações Unidas 18001, 04795-900 São Paulo, SP, Brasil. Auxílio financeiro: CNPq and AgrEvo.

Endereço para correspondência: Dra. Liléia Diotaiuti. Centro de Pesquisas René Rachou/FIOCRUZ. Av. Augusto de Lima 1715, 30190-002 Belo Horizonte, MG, Brasil.

Tel: 5531 295-3566; fax: 5531 295-3115.

e-mail: diotaiut@cpqrr.fiocruz.br

Recebido para publicação em 13/7/99.
} 
Pyrethroid insecticides are now widely used for the control of domestic triatominae, as part of an integrated strategy for the control of Chagas' disease ${ }^{13}$. However, in spite of excellent results with these compounds - especially in Brazil and neighboring countries of the Southern Cone ${ }^{311} 1314$ — their specific mode of action against triatominae remains unclear 61017 . Most importantly, the effect of sub-lethal doses has not been fully investigated, even though the active concentration of applied product is known to decline with time following an initial application ${ }^{4}$.

One of the earliest and still most widely used pyrethroids used for the control of triatominae is deltamethrin, generally applied as a wettable powder (WP) or flowable (SC) formulation at a target dose rate of $25 \mathrm{mg} \mathrm{ai} / \mathrm{m}^{2}$. At this dose rate, rapid mortality of exposed triatominae can be observed, but bioassays on treated house walls reveal that mortality declines over succeeding months, presumably due to progressive decay of the active ingredient ${ }^{4}$. In mosquitoes, it is commonly observed that casual contact with a surface treated with deltamethrin (or other pyrethroid) can produce an irritant effect, causing the insect to fly away - an effect known as excitorepellency ${ }^{2}$. Our aim in the present work was to determine if exposure to low doses of deltamethrin might elicit a similar effect in triatominae.

\section{MATERIAL AND METHODS}

Experiments were carried out in wooden boxes $54 \times 28 \times 8 \mathrm{~cm}$ (Figure 1) internally covered with medical gauze. Each box was divided by a central partition, allowing a $7 \times 4 \mathrm{~cm}$ opening to connect the two sections. Control boxes were completely untreated. For experimental boxes the gauze in left-hand section (side A) was impregnated with an SC formulation of deltamethrin at 2.5 or $5 \mathrm{mg} \mathrm{ai} / \mathrm{m}^{2}$, leaving the other side (side B) untreated. Laboratory-reared triatomine bugs were released into side $A$ of each box on the day after impregnation (day 0), and on days 30,60 and 120.

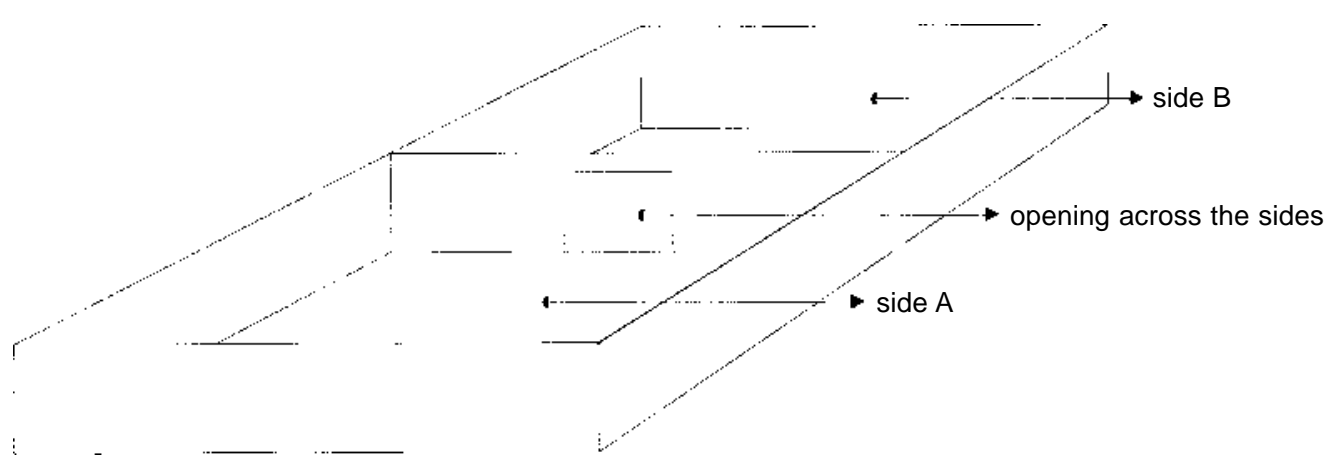

Figure 1 - Wooden box used in the experiments $(I=54 \mathrm{~cm} \times w=28 \mathrm{~cm} \times h=8 \mathrm{~cm})$, totally covered by a deltamethrin impregnated cloth (boxes of the groups not impregnated).

Initial experiments were carried out using batches of 60 adult Triatoma sordida (30 males and 30 females). For exposure at 120 days after impregnation of the gauze however, we used batches of 40 adult $T$. sordida, and also batches of 20 adults of $T$. infestans, Panstrongylus megistus, and Rhodnius neglectus, which are the species of greatest epidemiological importance in the State of Minas Gerais ${ }^{4}$. In each case, the number of bugs in the treated and untreated sections of the boxes was observed over a period of $24 \mathrm{~h}$, noting any attempts made by the insects to extend their wings and fly, and also scoring intoxication and mortality. At the end of the $24 \mathrm{~h}$ period, all bugs were removed to clean flasks and mortality was again scored 7 days later. 


\section{RESULTS}

The distribution of bugs between the two sides of the boxes is summarized in Table 1, and Figures 2 and 3 . In all cases, the bugs placed in control boxes (both sections untreated) showed very little change in their distribution over the periods of observation, whereas bugs in the treated sections

Table 1 - Percentage of paralyzed triatomines after 1, 2 and 24 hours (h) of contact with deltamethrin SC after cloth impregnation and mortality (corrected by Abbott's formula) of the insects after seven days (d).

\begin{tabular}{|c|c|c|c|c|c|c|c|c|c|c|c|c|c|c|c|}
\hline \multirow[b]{3}{*}{ Time } & \multicolumn{15}{|c|}{ Species } \\
\hline & \multicolumn{4}{|c|}{$\begin{array}{l}\text { Triatoma sordida } \\
\qquad(\mathrm{n}=40)\end{array}$} & \multicolumn{4}{|c|}{$\begin{array}{l}\text { Panstrongylus megistus } \\
\qquad(\mathrm{n}=20)\end{array}$} & \multicolumn{4}{|c|}{$\begin{array}{l}\text { Rhodnius neglectus } \\
\qquad(\mathrm{n}=20)\end{array}$} & \multicolumn{3}{|c|}{$\begin{array}{l}\text { Triatoma infestans } \\
\qquad(\mathrm{n}=20)\end{array}$} \\
\hline & $1 \mathrm{~h}$ & $2 \mathrm{~h}$ & $24 h$ & $7 d$ & $1 \mathrm{~h}$ & $2 h$ & $24 \mathrm{~h}$ & $7 d$ & $1 \mathrm{~h}$ & $2 \mathrm{~h}$ & $24 \mathrm{~h}$ & $7 d$ & $1 \mathrm{~h}$ & $2 \mathrm{~h}$ & $24 h \quad 7 d$ \\
\hline $5 \mathrm{mg}$ ia $/ \mathrm{m}^{2}$ & 0 & $0^{\mathrm{a}}$ & 10 & 100 & 45 & 100 & 100 & 100 & 100 & 100 & 100 & 17.2 & 30 & $60^{\mathrm{a}}$ & 100 \\
\hline $2.5 \mathrm{mg} \mathrm{ia} / \mathrm{m}^{2}$ & 0 & $0^{\mathrm{b}}$ & 20 & 21.2 & 60 & 100 & 100 & 100 & 100 & 100 & 100 & 17.2 & 30 & $40^{\mathrm{b}}$ & 10017.6 \\
\hline Control & 0 & 0 & 2.5 & 17.5 & 0 & 0 & 0 & 15 & 0 & 0 & 5 & 5 & 0 & 0 & $10 \quad 15$ \\
\hline
\end{tabular}

T. sordida $\times$ T. infestans/2h; $a: p=0.0005 ; b: p=0.0005$

$\mathrm{n}=$ number of triatomines used.
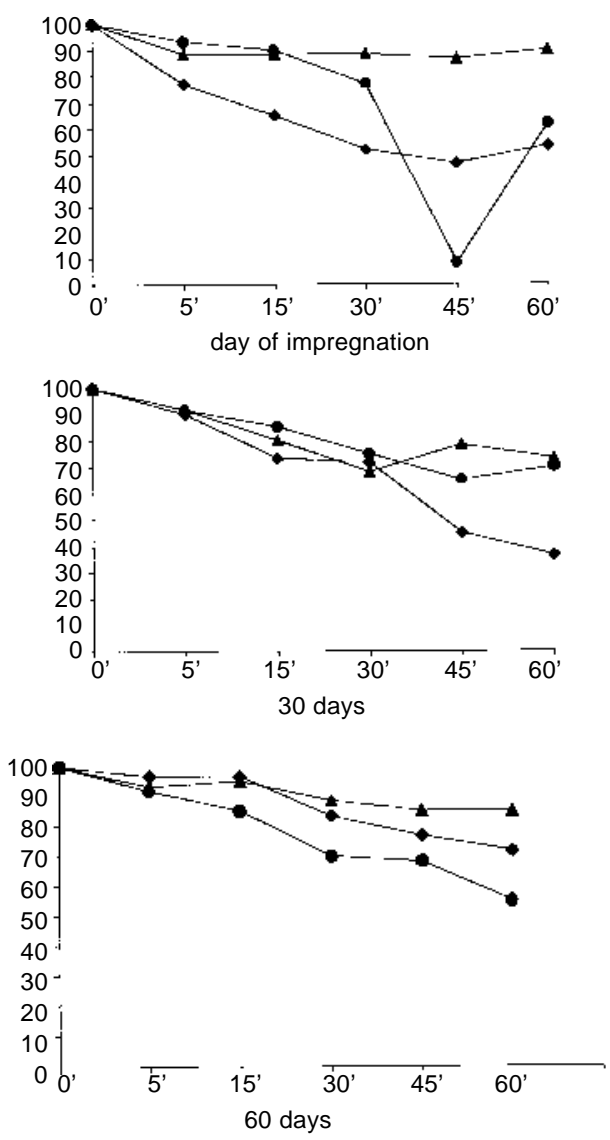

Figure 2 - Percentage of adults T. sordida at the side A (treated) of cloth covered boxes, at the day of impregnation with deltamethrin SC in different doses, 30 and 60 days after. 

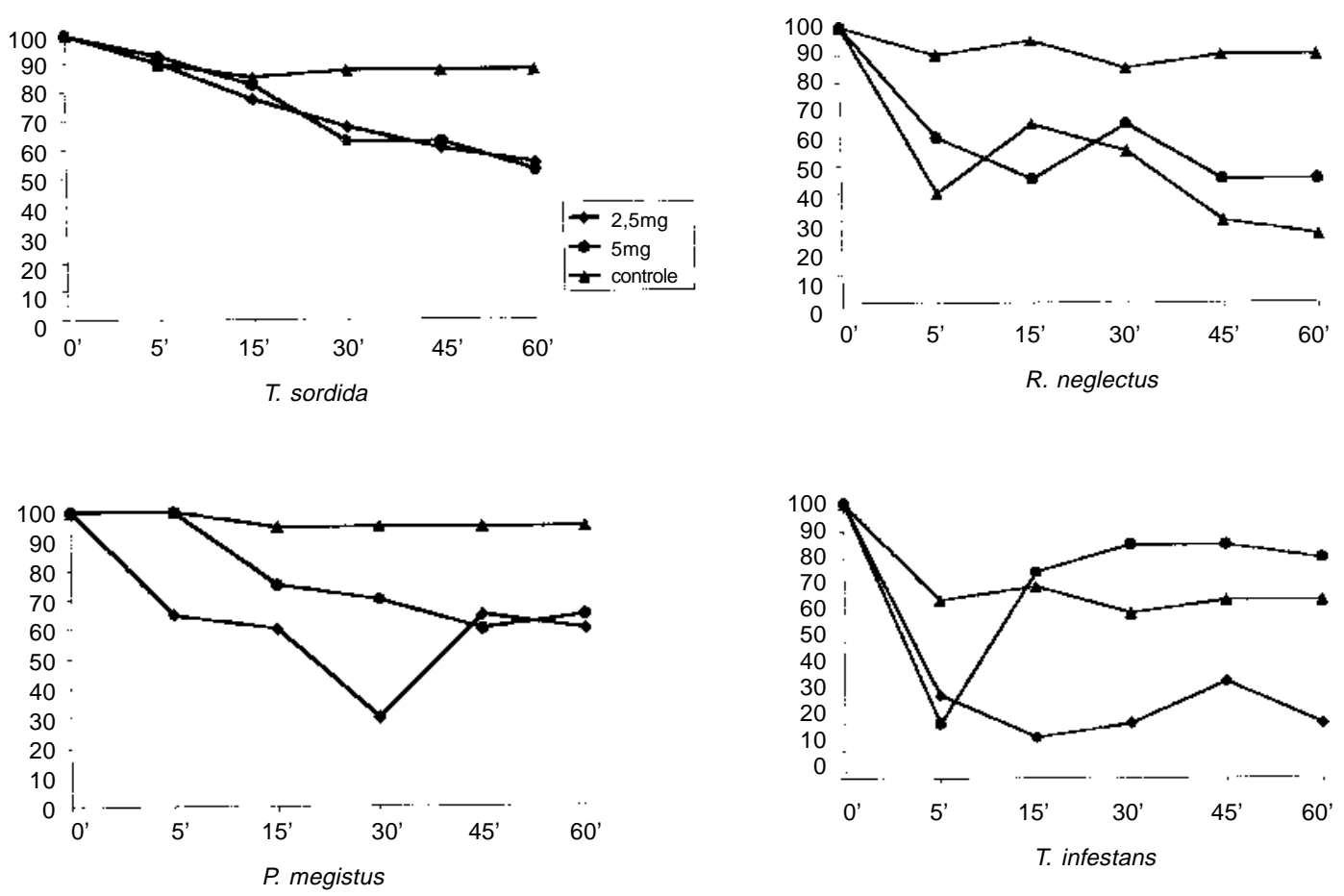

Figure 3 - Percentage of adults triatomines at the side A (treated) of cloth covered boxes, 120 days after the impregnation with deltamethrin SC.

showed considerable agitation, having changed their position during each 15 minute observation period. Moreover, there was a strong tendency for bugs to leave the treated sections. This effect was observed for all species, even on exposure to insecticide deposits aged for 120 days. The distributional changes appeared most marked in T. sordida, T. infestans, and $R$. neglectus, rather than in $P$. megistus, although $P$. megistus made several attempts to fly away from the treated surfaces (Figure 4).

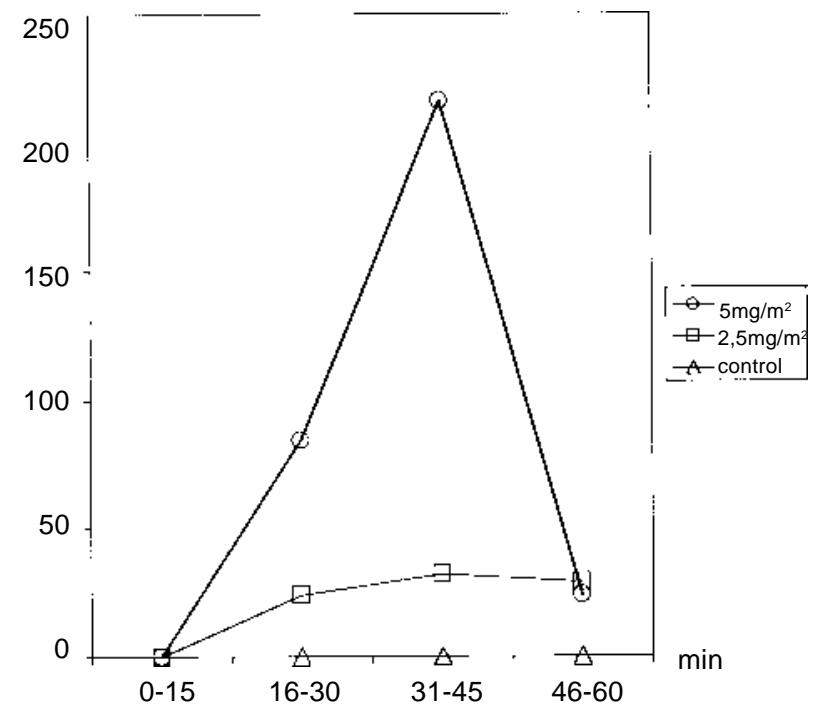

Figure 4 - Number of flight attempts of 10 couples of P. megistus left in contact with deltamethrin SC in different dosis, 120 days after impregnation. 
Intoxication of the insects, scored as apparent paralysis, was observed for all the $R$. neglectus within the first hour of exposure to the treated surfaces, and for all the P. megistus within 2 hours of exposure, whereas $T$. sordida and $T$. infestans were much less affected. Exposure to the higher dose of deltamethrin $\left(5 \mathrm{mg} \mathrm{ai} / \mathrm{m}^{2}\right)$ led to subsequent death in virtually all the $R$. neglectus, P. megistus and T. sordida, but killed only $47.7 \%$ of $T$. infestans (Table 1 ).

\section{DISCUSSION}

The flushing out activity of pyrethroids on $T$. infestans has been described by Wood et $\mathrm{al}^{17}$, using tetramethrin, deltamethrin and cypermethrin formulated as fumigant tablets or spray solutions of acetone and insecticide. Considering that all factors or substances that determine a negative orientation reaction may be considered repellent ${ }^{9}$, we are presenting here similar results using the deltamethrin formulated product, showing that exposure to medical gauze impregnated with the SC formulation produces irritation and negative tactic responses in four species of triatominae. In addition, we have demonstrated the persistence of this effect up to 120 days. This excito-repellency was partially masked in some cases - particularly $R$. neglectus - due to the high levels of intoxication and mortality observed even at the lowest dose tested after 120 days. Our results have also illustrated marked differences in susceptibility to deltamethrin, with $T$. infestans and $T$. sordida being the most tolerant, and $R$. neglectus and $P$. megistus the most susceptible. Similar differences in susceptibility were noted by Colas and Delabarre (1982) ${ }^{1}$. Nevertheless, it seems worth emphasizing that, in our experimental conditions and using impregnated cloth, high mortality was observed for all species even after just $24 \mathrm{~h}$ exposure to a 120-day old deposit of deltamethrin applied at only $10 \%$ of the recommended operational dose.
Our results also reveal differences in the type of negative tactics elicited by low-dose exposure to deltamethrin. Although the four species studied are all known to have the capacity to initiate flight ${ }^{8}$, this response was observed only in P. megistus, with the other three species showing only locomotory responses. $P$. megistus is known to initiate flight quite readily under appropriate conditions, and has been frequently captured in light traps ${ }^{15}$. T. infestans is a more reluctant flier ${ }^{7}$ although T. sordida seems to fly quite readily under natural conditions ${ }^{12}$.

In operational terms, these results are difficult to interpret. On the one hand, the excito-repellency effect may lead to increased locomotory activity amongst target vector populations, and so promote increased uptake of the insecticide as the insects walk over treated surfaces. But, such an effect could be counter-productive if target vectors could seek unsprayed surfaces on which to rest. The implication is that focal treatment of infested houses, with the idea of treating only those areas where bugs are most likely to congregate, should be discouraged in favor of more complete coverage of infested dwellings so that bugs cannot escape exposure to the insecticide. On the other hand, the excito-repellency effect of even sub-lethal aged deposits of deltamethrin may help to discourage recolonisation of treated houses by species such as $R$. neglectus and $P$. megistus coming from the silvatic environments.

\section{REFERENCES}

1. Colas R, Delabarre M. Control of vectors of main endemic diseases. In: Deltamethrin (monography), ISBN 2904125-01-9, Roussel Uclaf, Paris, p. 259-271, 1982.

2. Dartigues V. Use of Deltamethrin in the Control of Malaria. Roussel Uclaf Technical Bulletin, Division Agrovet., Paris, 1987.

3. Diotaiuti L, Paula OR, Falcão PL, Dias JCP. Evaluation of the vectorial program of Chagas' disease in the State of Minas Gerais (1979-1989), with special emphasis on Triatoma sordida. Boletin de la Oficina Sanitaria Panamericana 118:211-219, 1995.

4. Diotaiuti L, Pinto CT. Suscetibilidade biológica do Triatoma sordida e Triatoma infestans a deltametrina e lambdacyhalotrina em condições de campo. Revista da Sociedade Brasiliera de Medicina Tropical 24:151-155, 1991.

5. Guillen G, Diaz R, Jemio A, Alfred Cassab J, Pinto CT, Schofield CJ. Chagas' disease vector control in Tupiza, southern Bolivia. Memórias do Instituto Oswaldo Cruz 92:1-8, 1997.

6. Leahy JP. The Pyrethroid Insecticides. Taylos \& Francis, London, 1985.

7. Lehane MJ, McEwen PK, Whitaker CJ, Schofield CJ. The role of temperature and nutritional status in flight initiation by Triatoma infestans. Acta Tropica 52:27-38, 1992. 
8. Lehane MJ, Schofield CJ. Preliminary report on flight by some triatomine bugs. Transactions of the Royal Society of Tropical Medicine and Hygiene 70:526, 1976.

9. Mariconi FZAM. Insecticidas e seu emprego no combate as pragas. Tomo I. Defensivos, $3^{\text {rd }}$ edition, Livraria Nobel SA, São Paulo, 1977.

10. Pyrethroids Efficacy Group (PEG). The Pyrethroid Insecticides. A Scientific Advance for Human Welfare? Society of Chemical Industry. Reprinted from Pesticide Science (special issue) 27:335-469, 1990.

11. Schmunis GA, Zicker F, Moncayo A. Interruption of Chagas' disease transmission through vector elimination. The Lancet 348:1171, 1996.

12. Schofield CJ. Control of Chagas' disease. Pesticide Outlook 8:12-15, 1997.

13. Schofield CJ, Dias JCP. The Southern Cone initiative against Chagas' disease. Advances in Parasitology 42:127, 1999.
14. Silveira AC, Resende DF. Epidemiologia e controle da transmissão vetorial da doença de Chagas no Brasil. Revista da Sociedade Brasiliera de Medicina Tropical 27(supl. III):11-22, 1994.

15. Ventocilla JA, Silva P. Triatomíneos capturados em armadilha luminosa em área cacaueira da Bahia. Revista Brasiliera de Malariologia e Doenças Tropicais 20:161169, 1968.

16. Wood E, Licastro SA, Casabé N, Sivori J, Zerba E. Evaluation of the flushing out activity of pyrethroids on Triatoma infestans. Insect Science and Its Application 14:651-655, 1993.

17. Zerba $E$. Insecticidal activity of pyrethroids on insects of medical importance. Parasitology Today 4:S3-S7, 1988. 